\title{
ALTERATIONS OF FLUID AND ELECTROLYTE DISTRIBUTION AND RENAL FUNCTION IN DIARRHEA OF INFANCY ${ }^{1}$
}

\author{
By AVRUM L. KATCHER, 2 MARVIN F. LEVITT, ${ }^{3}$ AVRON Y. SWEET,4 AND \\ HORACE L. HODES, WITH THE TECHNICAL ASSISTANCE OF CHARLOTTE \\ SPANIER AND HERBERT HABER
}

\begin{abstract}
(From the Departments of Pediatrics and Medicine, The Mount Sinai Hospital, New York 29, N. Y.)
\end{abstract}

(Submitted for publication April 14, 1953; accepted May 29, 1953)

\section{INTRODUCTION}

The salt and water lost during acute diarrhea was originally presumed to derive almost entirely from the extracellular compartment $(1,2)$. Subsequently, it was realized that a significant loss of potassium occurred, in excess of that which might be attributed to the negative nitrogen balance $(3$, $4,5)$. This observation, with the assumption that transfer of body water depends upon primary transfer of base, led to the suggestion that considerable depletion of intracellular fluid also occurred $(5,6)$. Results obtained by balance studies, interpreted on the premise that the distribution of chloride is limited to the extracellular fluid, supported the belief that diarrhea of infancy induces primary depletion of extracellular water and salt with an additional loss of intracellular water and potassium $(7,8)$. These data also suggested that the early period of treatment may be characterized by a further depletion of the intracellular fluid volume, coexistent with an overexpansion of the extracellular compartment $(7,8)$.

The recent development of methods for the estimation of the fluid phase of the extracellular compartment with inulin, sucrose, and ferrocyanide, and of total body water with deuterium oxide and antipyrene suggested the use of these substances to estimate directly alterations in body water in diarrhea of infancy. Accordingly, serial determinations of plasma volume ( $\mathrm{T}-1824$ space), extracellular volume (inulin space), total body water (deuterium space), and renal function (inulin and $\mathrm{p}$-aminohippurate clearances) were made dur-

\footnotetext{
1 Read in part before the Society for Pediatric Research, Old Point Comfort, Va., May 6, 1952.

2 Sara Welt Fellow in Pediatrics.

8 Sara Welt and Rosenstock Fellow in Medicine; Assistant Attending Physician.

- Research Assistant in Pediatrics.
}

ing the acute stage of dehydration and during the subsequent period of treatment and recovery.

\section{METHODS}

Infants from two to eight months of age suffering from acute diarrhea were selected for study if clinical signs of dehydration (sunken fontanelle, soft eyeballs, dry mouth, decreased skin turgor) were present and if treatment could be safely postponed for six to eight hours. The volumes of distribution of $T-1824$, inulin and heavy water, glomerular filtration rate and renal plasma flow, hematocrit, plasma protein concentration and plasma electrolyte concentrations were measured prior to the institution of therapy.

These studies were repeated serially at two to seven day intervals during treatment. Following the initial studies, treatment was begun with 0.45 gram per cent solution of sodium chloride by continuous venoclysis at the rate of 150 to $200 \mathrm{ml}$. per kilogram of body weight per day. Appropriate quantities ( 75 to $200 \mathrm{ml}$.) of $1 / 6$ molar lactate were administered to correct metabolic acidosis. Some of the more severely ill infants received in addition 10 to $20 \mathrm{ml}$. per kilogram of blood or plasma.

After signs of dehydration had disappeared (usually at the end of the first 24 hours of treatment) intravenous infusions of 0.45 to 0.225 gram per cent solution of sodium chloride were continued in decreasing quantities until oral intake was considered adequate. After 12 to 24 hours of starvation the infants were fed dilute evaporated milk formulae. Thereafter, the volume of the feedings and the proportion of evaporated milk were gradually increased according to individual tolerance. The length of time during which parenteral therapy was continued varied from infant to infant ranging between two to seven days. Two of the infants received $6 \mathrm{mM}$ per kilogram per day of potassium chloride by mouth. Normal infants in the same age range, free of infection and metabolic disease on standard evaporated milk formulae, served as controls.

The volume of distribution of inulin was measured by the constant infusion technique, in which the amount of inulin excreted after the cessation of an equilibrating infusion is divided by the equilibrium plasma level (9). The infusion time necessary for the attainment of equilibrium distribution of inulin in the normal infant was estimated in two ways: 1) repeat determinations of the volume of distribution of inulin were made in the same 


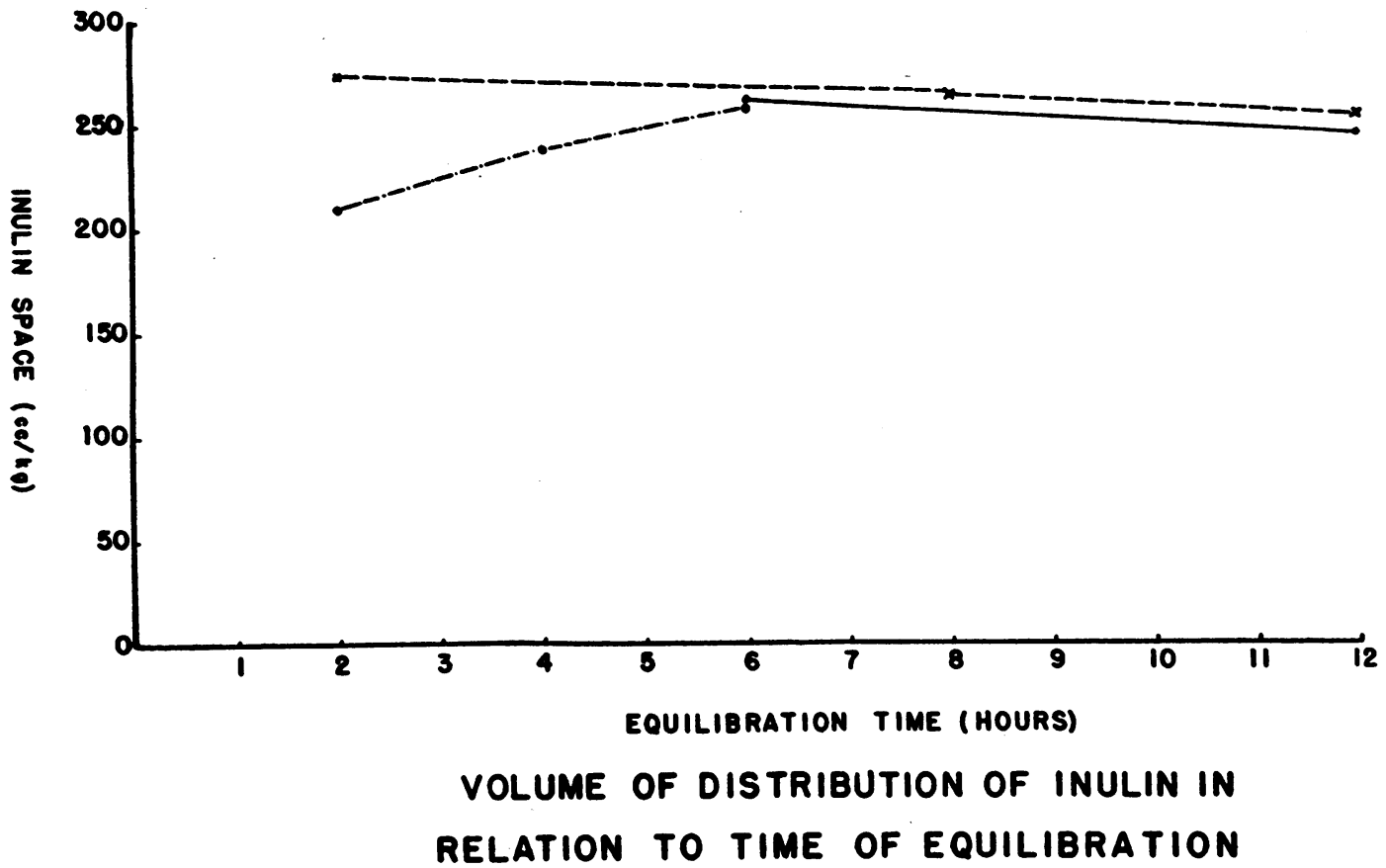

Fig. 1. Repeat Inulin Spaces in Three Normal Infants With Varying Infusion Prriods

Each type of line represents a separate subject.

infant with varying infusion times (Figure 1);2) the time necessary for the rate of excretion of inulin to equal the constant rate of infusion was determined. Both methods revealed that equilibrium distribution in the normal infant was achieved after two to four hours of a steady infusion. A comparable infusion time has been previously demonstrated to be necessary to attain equilibrium in adults (10). In a dehydrated infant it was shown that the rate of excretion equaled the rate of infusion three hours after a continuous infusion of inulin was begun. Accordingly, the equilibrating infusion was maintained for six hours in all cases. Each infusion was prepared to provide a plasma concentration of inulin of 30 to $50 \mathrm{mg}$. per $100 \mathrm{ml}$. when delivered at a rate of $10 \pm$ $0.15 \mathrm{ml}$. per hour with a Bowman pump. The total quantity of hypotonic salt solution administered during each space measurement was approximately 60 to $75 \mathrm{ml}$.

After the equilibrating infusion had been discontinued, the bladder was emptied and urine was collected through an indwelling catheter until all the inulin had been excreted. Complete excretion of the administered inulin in normal, dehydrated, and convalescent infants occurred within 12 to 18 hours (Figure 2). Urinary recoveries of inulin averaged 98.6 per cent (Table I).

The heavy water space was measured as the two and three hour volume of distribution of intravenously injected deuterium oxide (11). No correction was made for serum water concentration. Sufficient deuterium oxide was injected with a calibrated syringe to provide a concentration in vivo approximating 0.2 volumes per $100 \mathrm{ml}$. of body water. In all cases serial determinations of the serum deuterium concentration indicated that equilibrium had been attained within two hours.

Intracellular volume (non-inulin body water) was approximated as the difference between the simultaneous volumes of distribution of heavy water and of inulin. The total sodium and chloride content of the fluid phase of the extracellular compartment was estimated by multiplying the plasma sodium and chloride concentrations by the volume of distribution of inulin.

The volume of distribution of T-1824 was determined according to the method of Gregerson and Stewart using a single ten-minute blood specimen (12). Inulin and p-aminohippurate clearances were measured during the equilibrating infusion after the procedure of Smith and his co-workers (13). The bladder was washed between collection periods and at the end of the equilibrating infusion with distilled water and air.

TABLE I

Inulin recoveries*

\begin{tabular}{lcccc}
\hline \hline Patient & $\begin{array}{c}\text { Age } \\
\text { weeks }\end{array}$ & $\begin{array}{c}\text { Inulin } \\
\text { injected } \\
\text { mg. }\end{array}$ & $\begin{array}{c}\text { Inulin } \\
\text { excreted } \\
\text { mg. }\end{array}$ & $\begin{array}{c}\text { Inulin } \\
\text { recovered } \\
\%\end{array}$ \\
\hline H. F. & 3 & 240 & 236 & 98.4 \\
M. H. & 32 & 3410 & 3302 & 96.8 \\
B. H. & 19 & 1072 & 1041 & 97.2 \\
B. H. & 19 & 1050 & 1029 & 98.0 \\
R. H. & 4 & 450 & 475 & 105.0 \\
E. L. & 14 & 800 & 770 & 96.3 \\
\hline
\end{tabular}

* Average per cent of inulin recovered-98.6 per cent. 
TIME AFTER DISCONTINUANCE OF INFUSION

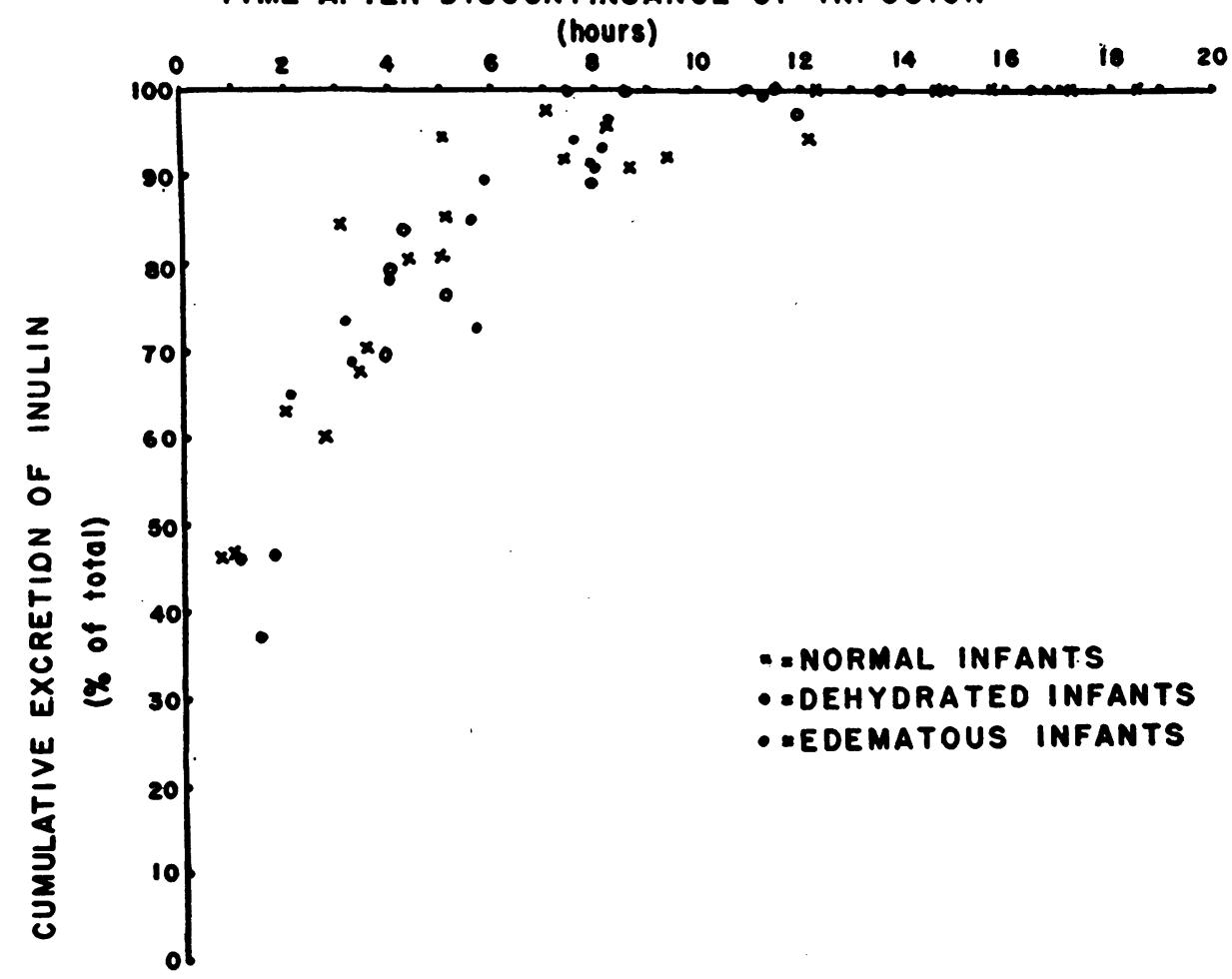

Fig. 2. Comparison of the Time Necessary for Total Excretion of InUlin in Normal, Dehydrated, and Edematous Infants

TABLE II

Body water determinations in normal infants

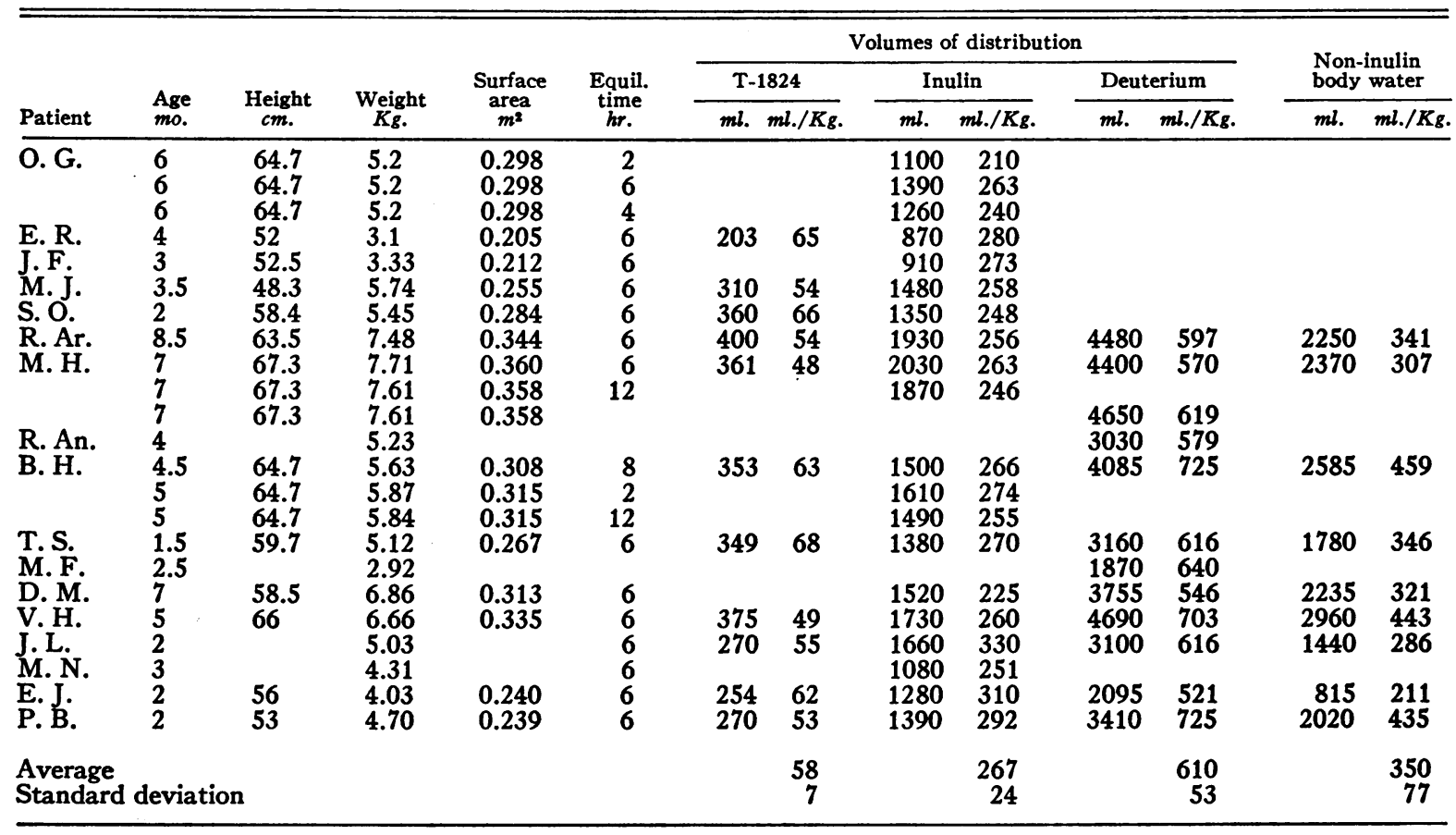


A. L. KATCHER, M. F. LEVITT, A. Y. SWEET, AND H. L. HODES

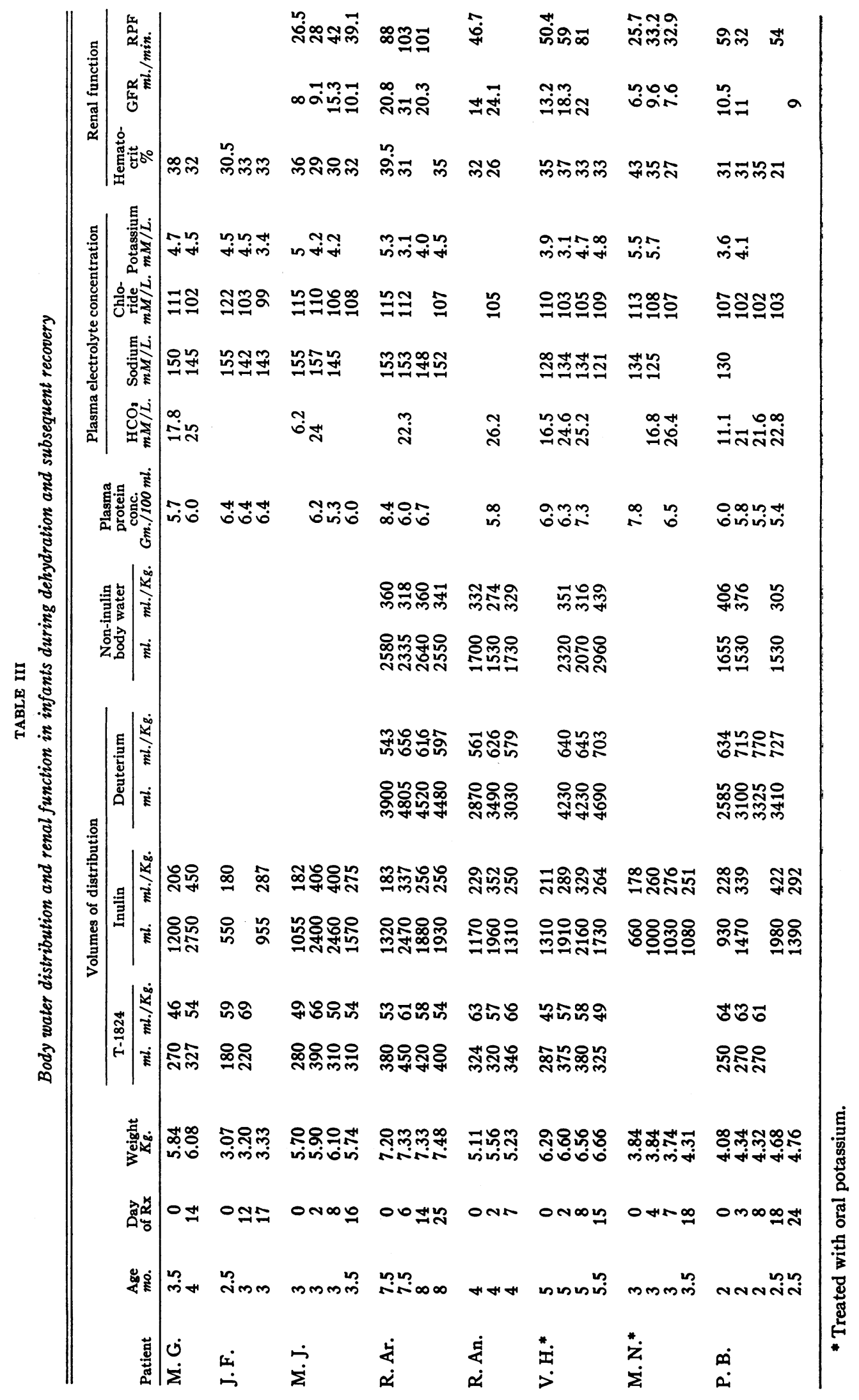


The deuterium oxide content of serum water was determined by the falling drop method (14). Inulin analyses were performed by the resorcinol technique (15) and p-aminohippurate by the method of Bratton and Marshall as modified by Smith et al. $(13,16)$. Sodium and potassium concentrations were analyzed in an internal standard Perkin-Elmer flame photometer (Model 52A). Chloride was determined by the Van Slyke and Hiller modification of the Sendroy technique (17); total protein by the copper sulfate method (18); hematocrit with a Wintrobe tube (19); plasma carbon dioxide content by the method of Van Slyke and Neill (20).

Infants were weighed daily on a tare balance sensitive to $\mathbf{4 5}$ grams at a weight of $\mathbf{3}$ kilograms. Surface area was calculated from height and weight by the formula of Dubois and Dubois as graphed by Boothby and Sandiford, $(21,22)$.

\section{RESULTS}

\section{A. Normal infants}

The volume of distribution of deuterium oxide determined 12 times in 11 normal infants averaged
$610 \mathrm{ml}$. per kilogram of body weight, with a range from 520 to $725 \mathrm{ml}$. per kilogram (Table II).

The volume of distribution of inulin, measured 19 times in 16 normal infants, averaged $267 \mathrm{ml}$. per kilogram with a range from 210 to $330 \mathrm{ml}$. per kilogram (Table II). Duplicate serial determinations of the absolute inulin space in three of these infants (O. G., M. H., B. H.) agreed within 10, 8 , and 1 per cent, respectively.

In nine normal infants the non-inulin body water averaged $350 \mathrm{ml}$. per kilogram with a range from 211 to $459 \mathrm{ml}$. per kilogram (Table II).

The volume of distribution of T-1824 in 10 normal infants averaged $58 \mathrm{ml}$. per kilogram with a range from 48 to $68 \mathrm{ml}$. per kilogram (Table II).

\section{B. Dehydrated infants}

The volume of the various body water spaces in the infants during dehydration are presented in

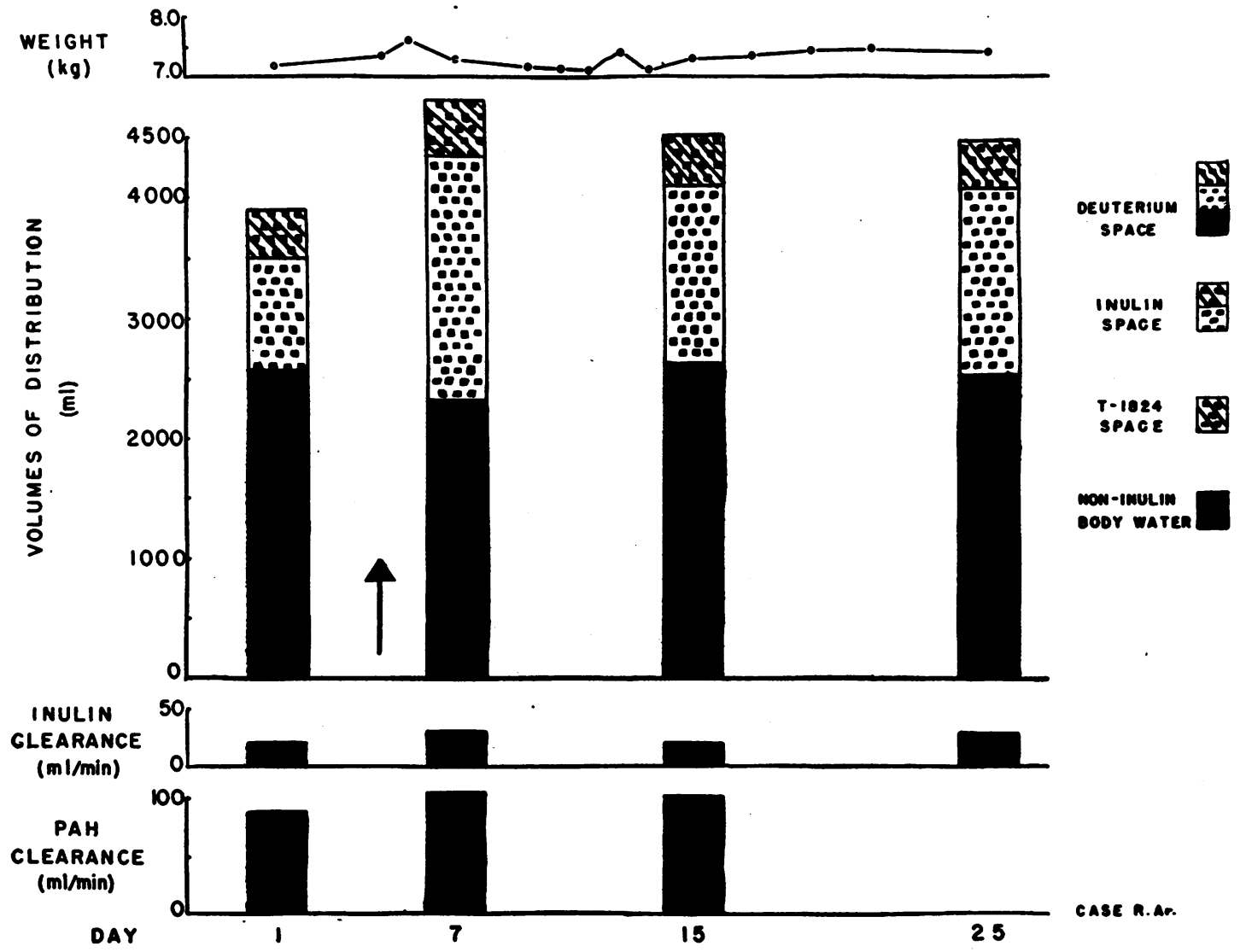

Fig. 3. Serial Changes in Body Weight, Total Body Water, Inulin Space, T-1824 Space, Non-Inulin Body Water, and Renal Function during Dehydration, Treatment, and Recovery in Subject R. Ar. The arrow designates the day in which parenteral therapy was discontinued. 


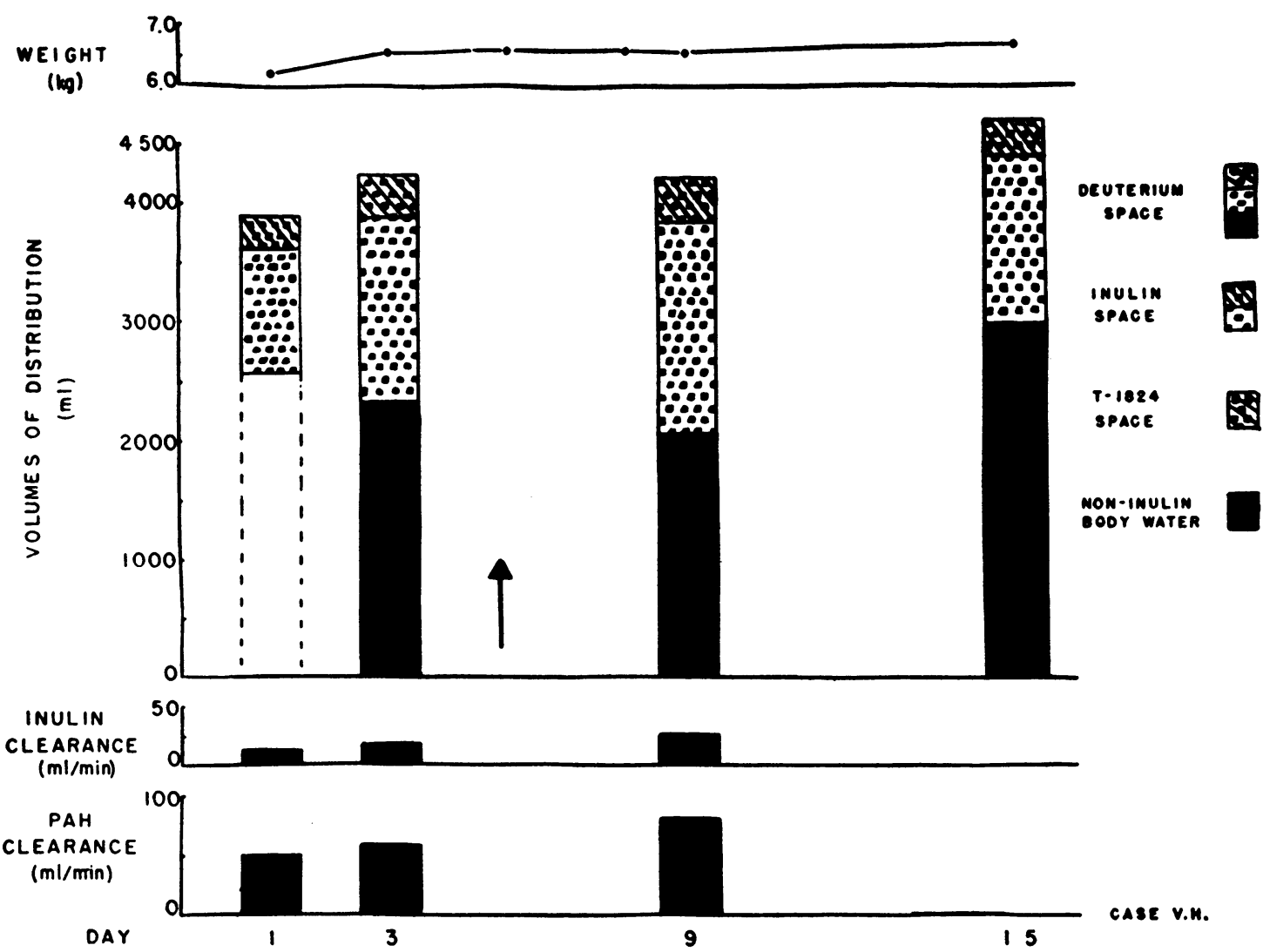

Fig. 4. Serial Changes in Body Weight, Total Body Water, Inulin Space, T-1824 Space, Non-Inulin Body Water, and Renal Function during Dehydration, Treatment, and Recovery in Subject V. H.

The arrow designates the day in whch parenteral therapy was discontinued. Dotted lines in first column indicate that total body water was not measured.

Table III. The volume of distribution of deuterium determined in three dehydrated infants averaged $580 \mathrm{ml}$. per kilogram of body weight at the time of admission, while volume of distribution of inulin in eight such subjects averaged $200 \mathrm{ml}$. per kilogram. In terms of absolute volumes, the inulin and heavy water spaces in three infants at time of admission averaged 400 and $500 \mathrm{ml}$., respectively, less than when these patients were fully recovered. The volume of the non-inulin body water in the dehydrated infants remained within the wide range of normal. The T-1824 space averaged $54 \mathrm{ml}$. per kilogram which was only $4 \mathrm{ml}$. per kilogram below the average values obtained in the same infants following recovery.

\section{Infants during treatment and after recovery}

Data obtained in three patients reveal that after one or two days of therapy the volume of distribu- tion of deuterium increased to values which approximated those obtained after complete recovery (Table III). Simultaneously, the volume of distribution of inulin expanded to an average value of $367 \mathrm{ml}$. per kilogram. This represents an increment of $75 \mathrm{ml}$. per kilogram above the average value obtained when the patients were fully recovered. Three of the infants concomitantly developed puffiness of the eyelids and face. The expansion of the inulin space to a supernormal volume appeared within two days after onset of therapy. In some instances these high values persisted for 10 days after parenteral fluids were discontinued-a period of 14 days (Table III, Figures $3,4)$.

The overexpansion of the volume of distribution of inulin in the early phase of therapy was not associated with a comparable increase in the volume of distribution of deuterium or of body weight. 
Accordingly, during this period of treatment the non-inulin body water decreased below values present on admission (Table III, Figures 3, 4). Thereafter, during convalescence (10 days to two weeks after therapy was begun), the volume of distribution of inulin reverted to normal control values with little change in total body water or body weight (Table III). By this time the volume of the non-inulin body water thereby expanded to normal control values (Table III, Figures 3, 4). The volume of distribution of T-1824 showed only slight changes. However, the small changes observed tended to vary in the same direction as those manifested by the inulin space (Table III). From the time of admission to the time of full recovery body weight increased an average of 60 grams per kilogram (Table III). One infant (M. N.) treated with potassium was the only subject who did not display excessive expansion of the volume of distribution of inulin (Table III) ; however, the inulin space of the other infant so treated (V. H.) expanded to a level $430 \mathrm{ml}$. above the final recovery volume while the non-inulin body water decreased to a level $900 \mathrm{~m}$. below the final volume (Table III, Figure 4).

Three infants on admission showed abnormally high plasma sodium and chloride concentrations (Table III). The other patients revealed no significant change in these concentrations. On admission the majority displayed a reduction in plasma $\mathrm{CO}_{2}$ content. Within 48 hours these changes in electrolyte concentrations usually reverted to normal. The course of recovery of the infants with hyperelectrolytemia was indistinguishable from that of the other patients. In most instances the plasma potassium concentration diminished from a high normal range on admission to a low normal range during the first week of therapy (Table III).

On admission the electrolyte deficit of the fluid phase of the extracellular compartment averaged 60 $\mathrm{mM}$ of sodium and $44 \mathrm{mM}$ of chloride, or $10 \mathrm{mM}$ of sodium and $7 \mathrm{mM}$ of chloride per kilogram of body weight below subsequent recovery values (Figure 5). The cases with hyperelectrolytemia demonstrated comparable deficits of total extra-

ADMISSION VALUES

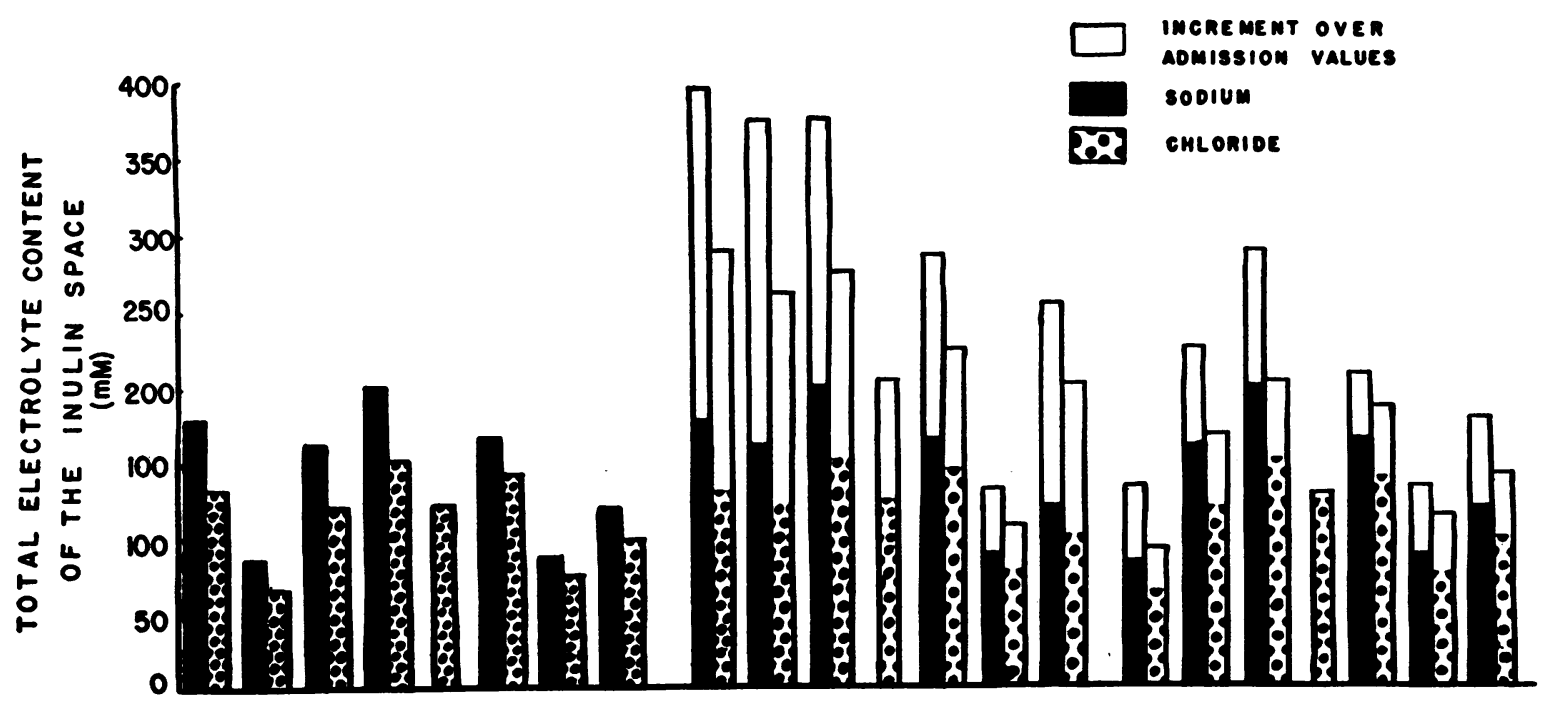

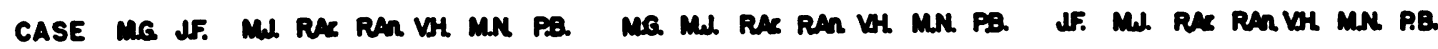
$\begin{array}{llllllllllllllllllllllll}\text { DASS AFTER } & 0 & 0 & 0 & 0 & 0 & 0 & 0 & 0 & 14 & 2 & 6 & 2 & 8 & 7 & 18 & 17 & 16 & 14 & 7 & 15 & 18 & 24\end{array}$

Fig. 5. Total Electrolyte Content of the Fluid Phase of the Extracellular Compartment (Inulin Space Times Plasma Electrolyte Concentration) during Dehydration, Maximal Increase During THERAPY AND RECOVERY 
cellular sodium and chloride. At the time of maximal expansion of the volume of distribution of inulin the total sodium contained in this compartment averaged $28 \mathrm{mM}$ per kilogram more than on admission and $15 \mathrm{mM}$ per kilogram more than subsequent recovery values. The comparable increase of the chloride contained in this compartment averaged $17 \mathrm{mM}$ per kilogram over admission values and $11 \mathrm{mM}$ per kilogram over subsequent recovery values (Figure 5).

In four of six subjects prior to the onset of therapy, the inulin and p-aminohippurate clearances were slightly lower than those determined after recovery (Table III). During the early period of therapy the inulin clearance and the filtration fraction tended to reach supernormal values (considerably in excess of the final recovery values) coincident with the maximal expansion of the inulin space.

Hematocrit and plasma protein concentrations on admission were within the normal range (Table III). After the onset of therapy they usually decreased. Subsequently, the hematocrit values and plasma protein concentrations reflected the use of plasma or whole blood transfusions.

\section{DISCUSSION}

The reliability of the volumes of distribution of inulin as a measure of the fluid phase of the extracellular compartment and of the volume of distribution of deuterium oxide as a measure of the total body water has been previously discussed (2326). These methods may be applied to the infant with little modification (see Methods). The volume of distribution of inulin and of heavy water in the control subjects (Table II) are in reasonable agreement with those reported by others (27-30).

The average expansion of the total body water detected from the time of admission to that of recovery is similar to that calculated by Darrow and his co-workers from balance studies in infants recovering from diarrhea (8). Similarly, the deficit of extracellular electrolyte exhibited on admission agrees with Darrow's data (8). However, from studies of a single infant dying from severe diarrhea, Steinitz and Weigert obtained data from which a total body water deficit of $210 \mathrm{ml}$. per kilogram may be calculated (31). This infant was undoubtedly more severely ill than those studied in our series. Indeed, it is probable that if the methods utilized in this study permitted the investigation of more severely ill infants, a greater depletion of the extracellular compartment and a consistent and significant decrease of the non-inulin fluid volume might have been detected during the stage of acute dehydration.

The overexpansion of the fluid phase of the extracellular compartment which was noted during the early period of therapy is in reasonable agreement with previous observations. Darrow and his co-workers demonstrated a significant expansion of the chloride space and a loss in the volume of "intracellular water" during the first phase of recovery from diarrhea (8). Twenty-five to fifty per cent of the infants with dehydration treated with a standard regimen displayed clinical edema comparable to that observed at the time of maximal expansion of the extracellular compartment in these subjects. Edema appearing during treatment for diarrhea has been repeatedly observed $(7,32$, 33).

The sodium, chloride, and water which expanded the volume of distribution of inulin beyond values obtained after recovery may have derived from the administered fluid and electrolyte which was retained, from salt and water which was transferred from non-inulin body fluid compartments, or from both. That a load of extracellular electrolyte may be excreted only after a delay of 24 to 36 hours in the normal infant and adult has been repeatedly demonstrated (34-38). Indeed, a normal infant may retain saline given subcutaneously for as long as five days (39). Furthermore, renal function and the rate of salt excretion is reduced during the stage of hydropenia and electrolyte deficiency $(40,41)$. Increased adrenal cortical activity with a resultant decrease of sodium and chloride excretion may be expected under stress of infection, fever, dehydration, and trauma subsequent to admission (42). The large amounts of sodium, chloride and water retained thereby account in large part for the overexpanded volume of distribution of inulin detected during therapy.

The retention of salt and water does not, however, explain entirely the excessive increase in the volume of distribution of inulin. In the cases studied neither the volume of distribution of deuterium nor the body weight demonstrated an increment comparable to that of the inulin space. On the 
average, only half of the increment of the volume of distribution of inulin was accounted for by a concomitant increase in the volume of distribution of deuterium or of body weight ${ }^{5}$ (Table III, Figures $3,4)$. In each infant in whom simultaneous inulin and deuterium spaces were measured, therefore, the non-inulin fluid volume decreased significantly early in the treatment period (Table III, Figures 3, 4). Specifically, one infant (M. J.) displayed an expansion of the volume of distribution of inulin of $1,350 \mathrm{ml}$. over the admission value after 48 hours of parenteral fluid therapy. The electrolyte content of the fluid phase of the extracellular compartment increased by $195 \mathrm{mM}$ of sodium and 140 $\mathrm{mM}$ of chloride. However, the subject had received in this period of time only $125 \mathrm{mM}$ of sodium and $90 \mathrm{mM}$ of chloride, which were administered intravenously with $1760 \mathrm{ml}$. of water. Furthermore, this expansion of isotonic extracellular fluid volume persisted in some instances for 14 to 18 days, or for 10 days after discontinuance of parenteral therapy (Table III, Figures 3,4). Late in the treatment phase, when the inulin space reverted to control values, no comparable reductions in body weight or total body water were detected. The non-inulin fluid volume therefore did not expand until the second or third week of hospitalization (Table III, Figures 3, 4). These considerations suggest that, in part at least, the prolonged over-expansion of the volume of distribution of inulin without proportionate reduction in plasma electrolyte concentrations may be attributed to an endogenous redistribution of sodium, chloride, and water into the fluid phase of the extracellular compartment.

The source of the sodium, chloride, and water transferred into the volume through which inulin is distributed is not known. It may have arisen from the cells or from any of those tissues not readily accessible to the inulin molecule. These tissues may include bone and dense connective tissue (the "solid phase of the extracellular compartment”), succus entericus, or bile $(43-45)$. Significant quantities of salt and water may be confined

${ }^{5}$ During the early phase of treatment three infants (R. Ar., R. An., P. B.) exhibited an increment in total body water which averaged 350 grams more than that in body weight. It is likely that this discrepancy reflects the utilization of body solids by sick infants maintained on inadequate caloric intakes. in the solid phase of connective tissue (46). Large stores of labile sodium are located in the crystalline structure of bone; salt and water are contained in the gastrointestinal tract (47). The salt and water may derive, in part at least, from any one of these sources.

It is not certain why infants recovering from dehydration lose their facility for homeostatic extracellular volume control. In normal adults in whom the salt load was suddenly increased from 6 to 18 grams per day, the expansion in the volume of distribution of inulin was slight and persisted for only 24 to 48 hours (38). It has been demonstrated previously that desoxycorticosterone administration to the dog and cortisone or ACTH administration to man induces a simultaneous exogenous retention and endogenous redistribution of salt and water $(11,48)$. These hormones therefore may endogenously augment the extracellular volume. If hormone therapy is prolonged, redistribution is reversed and the total extracellular volume returns toward normal. These alterations are qualitatively similar to those observed in infants recovering from diarrhea. Thus it is conceivable that the concomitant redistribution and retention of salt and water observed in these infants may relate to increased adrenal cortical activity. Furthermore, recent studies have shown that an acute reduction in plasma volume may cause a rapid transfer of salt and water into the fluid phase of the extracellular compartment (49). Whether this acute redistribution is similarly mediated via adrenal activity is not known. In any event, the stimuli of plasma volume depletion and adrenal cortical stimulation are probably both present in infants suffering from acute diarrhea and may be related to the salt retention and redistribution that were observed in these infants.

The overexpansion of the fluid phase of the extracellular volume per se has not been shown to be deleterious in infants. Since continuous infusion of electrolyte solutions may be essential during the early treatment of diarrhea, the concern with possible untoward effects of an overload of electrolyte may lead to inadequate therapy. A repair solution recommended in order to avoid overtreatment (50) would have been less than adequate for repair of extracellular deficits within 48 hours in four of five cases studied. However, the decrease of the non-inulin body water during the early stage 
of recovery may be etiologically related to those fatalities which sometimes occur during treatment after extracellular dehydration has been corrected.

One patient who received early therapy with potassium was the only subject who did not display the characteristic pattern of body fluid alterations during treatment and recovery (M. N., Table III). One other case so treated underwent a typical course, however, and in Darrow's cases those infants who displayed changes most similar to those described here were subjects who received early potassium therapy (8). Whether the administration of potassium will regularly inhibit the progressive depletion of non-inulin body fluid is not yet known. Insofar as these stores of sodium and chloride derive from the solid phase of the extracellular compartment-bone and connective tissue (51) - one would not expect the administration of potassium to inhibit such a redistribution. Although a reduction in plasma volume was present during the stage of dehydration (Table III) neither this volume nor the hematocrit nor the plasma protein concentration afforded a reliable index of the diminution in the volume of the fluid phase of the extracellular space (11).

The association of increased glomerular filtration rate with an expanded volume of distribution of inulin has been previously observed under hormonal influence $(11,48)$. The retention of salt and water despite the concomitant increase in glomerular filtration rate reflects the enhanced rate of tubular resorption of salt during early therapy. This finding similarly suggests that increased adrenocortical activity may underlie the alterations which were noted.

\section{SUM MARY AND CONCLUSIONS}

1. In the normal infant two to eight months of age, the $\mathrm{T}-1824$, inulin, and deuterium volumes of distribution averaged 58, 267, and $610 \mathrm{ml}$. per kilogram, respectively.

2. In infants suffering from acute, moderately severe dehydration, there was a considerable diminution of total body water due chiefly to extracellular fluid loss. Early in the treatment phase (two to 14 days after the onset of therapy) the inulin space expanded to supernormal volumes. This overexpansion of the inulin space was not associated with a comparable increase in the deuterium space or of body weight. During convalescence (two to three weeks after the onset of therapy), a reduction of the inulin space to normal values without comparable fall in body weight or deuterium space was observed.

3. The $T-1824$ space increased to normal within two to three days after the onset of therapy.

4. Glomerular flltration rate tended to be low during the state of dehydration. Thereafter, the inulin clearance increased to levels higher than those observed after recovery. The maximal increase in filtration rate and inulin space coincided.

\section{REFERENCES}

1. Gamble, J. L., Dehydration. Am. J. Dis. Child., 1929, 38, 666 .

2. Gamble, J. L., Dehydration. New England J. Med., 1929, 201, 909.

3. Steinitz, F., Zur kenntniss der chronischen ernahrungsstorungen der sauglinge. Jahrb. f. kinderh., 1903, 57, 689.

4. Holt, L. E., Courtney, A. M., and Fales, H. C., The chemical composition of diarrheal as compared with normal stools in infants. Am. J. Dis. Child., 1915, 9, 213.

5. Gamble, J. L., Butler, A. M., and McKhann, C. F., The character of the electrolyte loss in diarrheal disease. Am. J. Dis. Child., 1931, 43, 691.

6. Gamble, J. L., Ross, G. S., and Tisdall, F. F., The metabolism of fixed base during fasting. J. Biol. Chem., 1923, 57, 633.

7. Darrow, D. C., The retention of electrolyte during recovery from severe dehydration due to diarrhea. J. Pediat., 1946, 28, 515.

8. Darrow, D. C., Pratt, E. L., Flett, J., Jr., Gamble, A. H., and Wiese, H. F., Disturbances of water and electrolyte in infantile diarrhea. Pediatrics, 1949, 3, 129.

9. Gaudino, M., and Levitt, M. F., Inulin space as a measure of extracellular fluid. Am. J. Physiol., 1949, 157, 387.

10. Gaudino, M., Schwartz, I. L., and Levitt, M. F., Inulin volume of distribution as a measure of extracellular fluid in dog and man. Proc. Soc. Exper. Biol. \& Med., 1948, 68, 507.

11. Gaudino, M., and Levitt, M. F., Influence of the adrenal cortex on body water distribution and renal function. J. Clin. Invest., 1949, 28, 1487.

12. Gregerson, M. I., and Stewart, J. P., Simultaneous determination of the plasma volume with T-1824, and the "available fluid" volume with sodium thiocyanate. Am. J. Physiol., 1939, 125, 142.

13. Smith, H. W., Finkelstein, N., Aliminosa, L., Crawford, B., and Graber, M., The renal clearances of substituted hippuric acid derivatives and other aromatic acids in dog and man. J. Clin. Invest., 1945, 24, 388. 
14. Keston, A. S., Rittenberg, D., and Schoenheimer, R., Determination of deuterium in organic compounds. J. Biol. Chem., 1937, 122, 227.

15. Schreiner, G. E., Determination of inulin by means of resorcinol. Proc. Soc. Exper. Biol. \& Med., 1950, 74, 117.

16. Bratton, A. C., and Marshall, E. K., Jr., A new coupling component for sulfonilamide determination. J. Biol. Chem., 1939, 128, 537.

17. Van Slyke, D. D., and Hiller, A., Application of Sendroy's iodometric chloride titration to proteincontaining fluid. J. Biol. Chem., 1947, 167, 107.

18. Phillips, R. A., Van Slyke, D. D., Dole, V. P., Emerson, K., Jr., Hamilton, P. B., and Archibald, R. R., Copper sulfate method for measuring specific gravities of whole blood and plasma. Don Baxter, Inc., Glendale, Calif., 1945.

19. Wintrobe, M. M., Clinical Hematology, Lea \& Febiger, Philadelphia, Pa., 1942, 180.

20. Van Slyke, D. D., and Neill, J. M., The determination of gases in blood and other solutions by vacuum extraction and manometric measurement. $J$. Biol. Chem., 1924, 61, 523.

21. Dubois, J., and Dubois, E. P., Clinical calorimetry, a formula to estimate the approximate surface area if height and weight be known. Arch. Int. Med., 1916, 17, 863.

22. Boothby, W. M., and Sandiford, R. B., Nomographic charts for the calculation of the metabolic rate by the gasometer method. Boston Med. \& Surg. J., $1921,185,337$.

23. Levitt, M. F., and Gaudino, M., Measurement of body water compartments. Am. J. Med., 1950, 9, 208.

24. Schloerb, P. R., Friis-Hansen, B. J., Edelman, I. S., Solomon, A. K., and Moore, F. D., The measurement of total body water in the human subject by deuterium oxide dilution, with a consideration of the dynamics of deuterium distribution. J. Clin. Invest., 1950, 29, 1296.

25. Prentice, T. C., Siri, W., Berlin, N. I., Hyde, G. M., Parsons, R. J., Joiner, E. E., and Lawrence, J. H., Studies of total body water with tritium. J. Clin. Invest., 1952, 31, 412.

26. Turner, L. B., and Levitt, M. F., The extracellular compartment: a comparison of the chloride and inulin spaces. J. Mt. Sinai Hosp., 1953, 19, 653.

27. Calcagno, P. L., Husson, G. S., and Rubin, M. I., Measurement of "extracellular fluid space" in infants by equilibration technic using inulin and sodium ferrocyanide. Proc. Soc. Exper. Biol. \& Med., 1951, 77, 309.

28. Iob, V., and Swanson, W. W., Mineral gtowth of the human foetus. Am. J. Dis. Child., 1934, 47, 302.

29. Flexner, L. B., Wilde, W. S., Proctor, N. K., Cowie, D. B., Vosburgh, G. J., and Hellman, L. M., The estimation of extracellular and total body water in the newborn human infant with radioactive sodium and deuterium oxide. J. Pediat., 1947, 30, 413.
30. Friis-Hansen, B. J., Holiday, M., Stapleton, T., and Wallace, W. M., Total body water in children. Pediatrics, 1951, 7, 321.

31. Steinitz, F., and Weigert, R., Uber den Einfluss einseitiger Ernährung mit Kohlehydraten auf die chemische Zusammensetzung des Säuglingskörpers. Beitr. z. Chem. Physiol. u. Path. (Hofmeister's), 1905, 6, 206.

32. Karelitz, S., Continuous intravenous therapy in pediatrics, with special emphasis on its use in alimentary toxicosis. Acta paediat., 1933, 16, 546.

33. Marriott, W. McK., Hartmann, A. F., and Senn, M. J. E., Observations on the nature and treatment of diarrhea and the associated systemic disturbances. J. Pediat., 1933, 3, 181.

34. Stewart, J. D., and Rourke, G. M., The effects of large intravenous infusions on body fluid. J. Clin. Invest., 1942, 21, 197.

35. Grant, H., and Reischsman, F., The effects of the ingestion of large amounts of sodium chloride on the arterial and venous pressures of normal subjects. Am. Heart J., 1946, 32, 704.

36. Crawford, B., and Ludemann, $H$., The renal response to intravenous injection of sodium chloride solutions in man. J. Clin. Invest., 1951, 30, 1456.

37. Gamble, J. L., Wallace, W. M., Eliel, L., Holliday, M. A., Cushman, M., Appleton, J., Shenberg, A., and Piotti, J., Effects of large loads of electrolyes. Pediatrics, 1951, 7, 305.

38. Levitt, M. F., Turner, L. B., and Sweet, A. Y., Body fluid distribution following sudden changes in salt intake. Unpublished data.

39. Hamilton, B. (referred to by Bridge, E. M., in a discussion-Proceedings of Annual Meeting of American Pediatric Society). Am. J. Dis. Child., 1046, 72, 483.

40. Young, W. F., and McCance, R. A., Secretion of urine by dehydrated and normal infants. Arch. Dis. Childhood, 1942, 17, 65.

41. Calcagno, P. L., and Rubin, M. I., Effect of dehydration produced by water deprivation, diarrhea, and vomiting on renal function in infants. Pediatrics, 1951, 7, 328.

42. Selye, H., Textbook of Endocrinology. Acta Endocrinologica Inc., 1947.

43. Cotlove, E., Inulin and chloride space in muscle. Federation Proc., 1952, 11, 28.

44. Wallace, W. M., Some aspects of the chemical composition, physiology and pathology of intracellular fluid. Pediatrics, 1952, 9, 141.

45. Kruhoffer, P., Inulin as an indicator for the extracellular space. Acta Physiol. Scandinav., 1946, 11, 16.

46. Manery, J. F., and Hastings, A. B., The distribution of electrolytes in mammalian tissue. J. Biol. Chem., 1939, 127, 657.

47. Bergstrom, W. H., Bone as a sodium and potassium reservoir. J. Clin. Invest., 1952, 31, 617. 
48. Levitt, M. F., and Bader, M. E., Effect of cortisone and ACTH on fluid and electrolyte distribution in man. Am. J. Med., 1951, 11, 715.

49. Levitt, M. F., Turner, L. B., and Sweet, A. Y., The effect of experimental venous obstruction on salt and water distribution and excretion in man. $J$. Clin. Invest., 1952, 31, 885.
50. Butler, A. M., Talbot, N. B., Crawford, J. D., MacLachlan, E. A., and Appleton, J., Parenteral fluid therapy in diarrheal disease. Am. J. Dis. Child., 1946, 72, 481.

51. Levitt, M. F., Turner, L. B., and Sweet, A. Y., The role of bone and connective tissue in the defense of extracellular fluid composition. (In preparation.) 